\title{
ASIMILASI SOSIAL MUALLAF TIONGHOA DI KECAMATAN PONTIANAK BARAT KOTA PONTIANAK
}

\author{
Baharuddin
}

\begin{abstract}
This research aims at describing a social assimilation of Tionghua muallaf (converted Muslim) residing in West Pontianak County, Pontianak City of West Kalimantan. There are several important findings of this work with regards to the Tionghua muallaf including; Social Condition Group of Tionghoa Muallaf In West Pontianak District, Assimilate Process of Tionghoa Muallaf After Entering Islam, and Resistances Group of Tionghoa Muallaf.

The social condition of the muallaf suggests that they convert to Islam due to several reasons including their new marital life, receiving hidayah (guidance) from Allah, having knowledge about Islam before converting to Islam, having seen the benefits and chances in their life such as satisfaction, peace, prosperity, patient, high respect to gifts from Allah and wanting to have a better life and clean heart in life. The convert process includes through religious clerics, the local offices of religious affair (Kantor Urusan Agama), extended parents and respected public figures; the assimilation process of the Tionghua muallaf shows that the Tionghua muallaf have not had better social relation with their Muslim neighbors, not been courageous enough to practice their Islam in public sphere, not done better assimilation within their new communities and not decided their direction of their new life with Islam; the discussion of constrain issues of the Tionghua muallaf indicate that they practice close relation within them, do not have jobs, do not have good motivations of life due to their lacks of hard work courage, they are low respect

to their opportunities and self capabilities, selfish and less public care, good communication, less understanding of their new life, do not have enough time to study Islam due to the limitation of available teachers, practice Islam with instant hopes, think about economic benefits in all activities and are less involved in both formal and informal religious support institutions.

Based on the above findings the work proposes some important recommendations including (1) it is important to encourage/develop a better relationship model; (2) it is also important to encourage/develop an Islamic and based-on-Qur'an-and-Hadist environment for the Tionghua muallaf; (3) if there is any problems and issues related to practicing Islam the muallaf should soon ask Islamic clerics and teachers; (4) it is important to give guidance and care to the muallaf having low courage to maximally practice their new religion; and (5) there should be a call to practice harmonic life within the Tiongoua muallaf with better daily interaction, care and hospitality.
\end{abstract}

Key words: assimilation, muallaf and Tionghoa 


\section{A. Pendahuluan}

Kehidupan pindah agama merupakan proses perubahan sosial serta perubahan pandangan dalam kehidupan seorang manusia. Berangkat dari hal tersebut banyak manusia pindah agama tetapi ajaran serta pandangan hidup termasuk juga didalamnya dalam hal ibadah masih melekat dan ajaran baru belum dipelajari sehingga diperlukan pembinaan, bimbingan serta bantuan dari pembuka agama untuk memberikan pemahaman ajaran yang memadai dalam meningkatkan kualitas hidup serta peningkatan keimanan dan ketaqwaan kepada Tuhan Yang Maha Esa.

Organisasi Muallaf Tionghoa di Kota Pontianak berdiri pada tanggal, 15 September 2006, dan disahkan dalam akte notarisnya tanggal, 27 Desember 2006, diberi nama Forum Komunikasi Pembinaan Muallaf Tionghoa (FKPMT). Pada awalnya diketuai oleh Iwan Sutanto (Heng Ngo Sin) dan sekarang Drs. Hermanto. Forum Komunikasi Pembinaan Muallaf Tionghoa (FKPMT) ini berasaskan Islam, Pancasila dan UUD 1945, bersifat terbuka, mandiri, bebas, dan tidak bertalian dengan organisasi politik manapun.

komunikasi muallaf Tionghoa di Kecamatan Pontianak Barat Kota Pontianak secara global dapat tergambarkan bahwa kurangnya memiliki hubungan yang baik dengan para tetangga dan kelompok masyarakat lainnya. Faktor penyebabnya seperti: 1. Karena mereka orang baru, sehingga pergaulan dengan tetangga serta kepada sesama kurang baik, 2. Mereka tertutup sehingga dengan masuknya mereka ke Islam mereka merasa orang baru dan merasa malu untuk bergaul dengan orang lain yang ada disekitar tempat tinggal.

\section{B. Kondisi Sosial Muallaf Tionghoa di Kecamatan Pontianak Barat}

Masuknya etnis tionghoa ke dunia Islam sangat variatif dari 1 tahun sampai 22 tahun. Hal ini menjadikan mereka sangat berbeda pula pemahaman serta kedalaman dalam menjalankan agama barunya. Berangkat dari sebabnya mereka masuk Islam seperti yang dipaparkan dalam data pada pembahasan terdahulu, diantaranya seperti:

a. Masuk Islam karena menikah

b. Masuk Islam karena mendapatkan hidayat atau petunjuk dari Allah SWT.Tidak semua orang dalam dunia mendapatkan hidayah langsung dari Allah SWT.

c. Masuk Islam karena sudah mengenal dunia Islam sebelumnya.

d. Masuk Islam melihat manfaat serta perubahan dari kehidupan seperti 
ketenagan jiwa, rasa puas dan tingkat menyukuri nikmat sangat tinggi.

e. Masuk Islam membawa barokah karena dengan masuk Islam mereka merasakam hidup terarah dan hasil dari kerja mereka juga dapat dirasakan baik untuk nafkah kehidupan sehari-hari maupun untuk ibadah yang akhirnya mengharapkan ridho dari Allah SWT semata.

f. Masuk Islam ingin mendapatkan kedamaian, kesejahteraan dan kesabaran dalam menjalani hidup kedepannya lebih baik kedepannya.

g. Masuk Islam karena ingin mendapatkan ketenangan jiwa dan kesucian hati dalam menenjalani kehidupan.

Dalam memahami serta mengetahuai kondisi sosial muallaf Tionghoa dapat dilihat dari teori yang Menurut Elly M. Setiadi dan Usman Kolip (2011:81) menyatakan bahwa syarat asimilasi yatu:

a. Kelompok manusia yang berbeda kebudayaannya. Perpecahan antarkelompok dalam satu wilayah kultur (kebudayaan) tidak digolongkan asimilasi.

b. Orang perorangan sebagai warga kelompok tadi saling bergaul secara langsung dan intensif untuk waktu yang lama. Tanpa melalui pergaulan dalam kurun waktu tertentu maka asimilasi tidak akan tercapai.

c. Kebudayaan dari kelompok manusia tersebut masing-masing berubah dan saling menyesuaikan diri.

Dari teori diatas dapat dijabarkan mengenai kondisi muallaf Tionghoa di Kecamatan Pontianak Barat Kota Pontianak bahwa:

Kelompok manusia yang berbeda kebudayaannya. Kebudayaan yang ada merupakan warisan dalam perjalanan kehidupan, berangkat dari hal tidak banyak manusia dapat melupakan kebudayaan lama, ketika mereka dalam kehidupan baru dengan agama yang berbeda serta nilainilai bidaua yang ada juga sanagat jauh berbeda.

Ada beberapa hal yang didapatkan dengan saling memahami antar sesama seperti: Bargaining, Kooptasi (cooptation), Koalisi (coalition), dan Jointventrue.

Dalam melakukan pelaksanaan pengislaman para muallaf Tionghoa ada dilakukan di rumah keluarga asalnya bagi orang tua yang tidak memasalahkan anaknya masuk Islam dan ada juga yang di Islamkan dirumah pegawai serta ulama yang diberikan wewenang untuk melakukan pengislamannya. Kemudian ada juga melakukan pengislamannya di 
Masjid karena langsung diajarkan Syahdat serta tata cara mendirikan ibadah sholat.

Masuknya ke di dunia Islam sebagai hal baru bagi mereka tentu masih banyak yang harus dibimbing dan diarahkan.Dari sebagian besar hasil wawancara mengatakan bahwa $87.5 \%$ mereka belum mengenal dan melaksanakan dunia Islam secara benar, baik berupa: ibadah seperti sholat, mengaji dan baca buku agama serta sisa $12,5 \%$ mereka sudah mengenal dunia Islam karena pada waktu sekolah dan sebelum masuk Islam mereka mendapatkan ilmu Islam melalui pelajaran agama dan ada juga yang mendapatkan ilmu Islam dari teman dan tetangga.

Kondisi sosial muallaf Tionghoa dilihat dari masuknya ke dunia Islam ada masalah secara ibadah tetapi hal tersebut dapat diatasi dengan belajar sungguhsungguh.Hasilnya juga tidak banyak diantara mereka yang mendapat ajaran Islam secara baik dan benar. Ada beberapa hal yang menyebabkan mereka tidak dapat mendapatkan ilmu Islam secara maksimal seperti:

a. Guru ngaji belum banyak dan waktu ngajar tidak lama.

b. Guru belajar agama masih sangat minim

c. Waktu belajar sangat terbatas karena mereka juga harus kerja untuk memenuhi nafkah diri dan keluarganya. d. Kurangnya buku-buku agama untuk dipelajari secara kontinyu.

e. Sarana dan prasarana yang kurang memadai juga dapat menyebabkan terhenti atau tidak maksimal dalam belajar, seperti: perpustakaan Islam kurang banyak dan sangat minim jumlah bukunya.

Kondisi sosial muallaf Tionghoa dalam berinteraksi dengan warga kebanyaknya dari mereka belum baik karena masih ada rasa malu, takut, menutup diri dan selalu merasakam dirinya ada orang baru .Hal ini juga diperlukan pendekatan dari pihak Islam untuk memberikan motivasi serta pendekatan baik itu dengan bergaul maupun dengan memberikan ilmu agama yang sesuai ajaran Islam. Pada kehidupan keseharian dijalankan dengan baik hal tersebut dipaparankan oleh para informan dan ada masalah yang dihadapi, seperti cobaan hidup, tidak diterima dikeluarga asal, tidak mendapatakan warisan harta dari orang tua, dibuang dari keluarga atau dianggap sudah bukan keluarganya lagi dan terhempitnya ekonomi.

Dalam memperbaiki pendidikan akan moral serta akhlak kepada muallaf Tinghoa yang berpedoman pada jaran Islam menjadi sangat penting karena hal tersebut merupakan pondasi awal dalam melakukan aktivitas kehidupan dengan 
warga baru, agama baru dan budaya baru yang ada. Dalam meningkatkan kualitas kehidupan dari para muallaf Tionghoa diperlukan adanya pemberikan penanaman serta bimbingan langsung terhadap mereka sehingga pada akhirnya akan merasa mendapat perhatian dari para tokoh agama dan masyarakat.

Adapun faktor yang menyebabkan kondisi sosial dalam masyarakat muallaf Tionghoa tidak berjalan dengan baik karena hanya memikirkan diri sendiri dan tidak mau bekerja keras maka orang tersebut menyebabkan sistem sosial tidak dapat berjalan dengan baik. Orang yang berorientasi hidup enak sesaat maka hal tersebut dapat membuat atau menjadikan sistem sosial tidak berjalan dengan baik karena banyak sekali sesuatu aturan dibuat tidak ditaati dengan baik sehingga aturan serta peraturan yang sudah dibuat tidak berjalan dengan baik.

\section{Proses Asimilasi muallaf Tionghoa} di Kecamatan Pontianak Barat

Menurut Soejono Soekanto (2002:82-83) faktor-faktor yang mempermudah terjadinya asimilasi antara lain adalah:

a. Teloransi, Dilapangan masih ditemukan banyak hal yang mengarahkan makna toleransi tidak berjalan atau tidak dilaksanakan dalam kehidupan. Dalam hal ini membuat proses asimilasi muallaf Tionghoa tidak berjalan baik. Dilihat dari warga sekitar yang beragama Islam masih dirasakan kurang perhatian sepenuhnya dalam menghargai kehadiran para muallaf yang ada.

b. Kesempatan-kesempatan yang seimbang di bidang ekonomi sangat diperlukan sekali dalam kehidupan bermasyarakat. Sektor ekonomi merupakan hal penting dalam menjalani kehidupan tetapi hidup tidak harus selalu berorientasi kepada nilai ekonomi, karena dalam kehidupan sangat diperlukan rasa tenang, tetapi dunia sekarang sekotor ekonomi sangat menentukan ketentraman hidup yang ada.

c. Para muallaf banyak yang terputus warisan dari orang tua dengan pindah agama. Berangkat dari hal tersebut sangat diperlukannya pencerahan serta pemahaman dalam kehidupan mereka bahwa hidup ini tidak hanya mengejar ekonomi saja tetapi hal lain juga masih banyak perlu diperjuangkan.

d. Sikap menghargai orang asing dan kebudayaannya sangat diperlukan dalam kehidupan yang ada.Berangkat dari hal tersebut harus saling menghargai karena dengan seperti ini dapat membawa kedamaian dalam 
kehidupan.Orang asing atau orang yang baru pindah budaya adalah suatu kehidupan yang baru dalam menjalani kehidupannya sehingga masih banyak hal yang harus dibenarkan dan diluruskan dalam memperbaiki kehidupan sosial kemasyarakatan.

e. Kehidupan para muallaf Tionghoa masih dirasakan belum sepenuhnya masuk dalam budaya baru, sehingga budaya lama masih terbawa. Penanaman sifat positif dengan budaya baru merupakan hal yang harus dilakukan oleh para muallaf Tionghoa yang ada, sehingga mereka cepat diterima dan mendapatkan kehangatan dalam berhubungan dan berkomunikasi dengan sesama masyarakat dan warga yang ada.

f. Sikap terbuka dari golongan yang berkuasa dalam masyarakat harus dijalani dengan baik, sehingga para muallaf dalam memasuki budaya serta struktur kehidupan baru tidak merasa selalu dibiarkan. Hal semacam ini harus selalu dikedepankan sehingga terciptaan hubungan yang baik dan komunikasi intens dalam masyarakat. Fenomena keterbukaan dan membuka diri terhadap budaya baru dan budaya datang berdampak sangat positif, selagi hal yang dimasuknya bersifat positif dam membangun hubungan sosial menjadi lebih baik bersama.

Berangkat dari hal tersebut proses asimilasi yang dilakukan oleh komunitas muallaf Tionghoa terdapat ada beberapa hal seperti mencari kehidupan baru yang lebih baik dan mendapat ketentraman dalam hidup dengan tujuan bersama dalam mencapaikan kebaikan bersama. Proses asimilasi yang baik diharapkan memuat beberapa hal seperti: toleransi, mendapatkan kesamaan bersaing dalam bidang ekonomi, saling menghargai dengan perbedaan yang ada, memiliki tujuan bersama dan melaui perkawinan.

Faktor-faktor yang mempermudah bagi jalannya asimilasi di antaranya: Masyarakat terdiri dari orang-orang yang mempersatukan diri melalui relasi-relasi timbal balik yang pada hakekatnya merupakan proses kehidupan sosial mereka sendiri sejumlah aksi-aksi dan reaksi yang tidak terbilang banyaknya dari perorangan atau kelompok, dalam menyesuaikan diri dengan pola perilaku yang kolektif.Hal tersebut yang membuat muallaf Tionghoa melakukan interaksi yang terbangun dalam masyarakat belum terlihat secara baik karena antara reaksi dan aksi-aksi yang ada belum terhubungan dengan komuniatas sosial lainnya.

Persamaan dalam unsur-unsur budaya setiap kehidupan sangat 
berdampak pada hubungan baik atau buruk dalam lingkaran yang ada.Berangkat dari hal tersebut banyak hal yang harus diperhatikan dan ditingkatan sehingga unsur budaya dapat disamakan. Walaupun tidak secara sepenuhnya dapat disamakan sebaiknya dicari atau temukan unsur yang menjadi persamaan bukan menacari perbedaan yang ada semata. Karena dalam kehidupan tidak ada budaya yang berdiri sendiri tetapi banyak budaya lahirnya budaya suatu kelompok etnis dikarenakan ada proses pemaburan dari budaya asing (baru).

Persamaan budaya memang sangat mempermudah proses asimilasi muallaf Tionghoa khususnya di Kecamatan Pontianak Barat, sehingga diperlukan sejali bagaimana mereka dan kelompok etnis melohat persamaan dari bawaan dari masing-masing budaya yang ada. Budaya merupakan hal yang sangat sensitive dalam kehidupan berangkat dari hal tersebut yang ada harus dilestarikan. Kalau kita masuk dalam budaya baru maka budaya barulah dipakai dalam kehidu-pan yang ada.Pandangan ketidak-absahan (perceived illlegiti-macy) hubungan antar kelompok agama secara sosiologis dan psikologis adalah diterima dan dapat diterimanya pengungkit (lever) untuk tindakan dan perubahan social dalam perilaku antar kelompok agama (intergroup beha-vior).
Dalam hal kelompok yang "inferior", fungsi pengungkit/pengaruh (leverage) terpenuhi dengan pandangan ketidaksahan hasil-hasil perbandingan antar kelompok; dalam hal kelompok-kelompok "inferior" yang sedang menuju perubahan, 'leverage'nya adalah keabsahan (legitimasi) citra perbandingannya yang baru (new comparative image); dalam hal kelompok-kelompok yang "superior" 'leverage'nya adalah keabsahan usahausaha untuk memelihara status perbedaan nilai manakala perbedaan nilai ini dipandang terancam.

Perkawinan campuran (amalgamation) merupakan hal dilakukan para muallaf Tionghoa di Kecamatan Pontianak Barat dalam mendapatkan atau menjalani agama baru.Dengan hal tersebut dapat membawa warna baru dalam kehidupan mereka dengan melihat dan memperhatikan secara baik budaya serta ajaran baru dalam menjalani kehidupan sehingga mencapai keluarga sakinah, mawadah dan warahmah. Budaya orang tua dalam hal itu adalah merupakan budaya lama dari para muallaf berdampak dalam hubungan setelah mereka masuk Islam, tetapi harus diperhatikan dan diusahakan dengan cepat untuk dibuang setidaknya tidak dilakukan sepenuhnya dalam menjalani kehidupannya.Budaya baru (Islam) merupakan sesuatu hal yang harus cepat 
dilakukan dan dipahami dalam pencapaian hubungan yang harmonis dalam kehidupan barunya. Tokoh agama dan keluarga barunya bersama-sama dan berusaha memberi-kan arahan dalam menjalankan budaya baru tersebut.Apa saja hal yang harus dilakukan dan mana yang harus ditinggalkan. Jangan dibiarkan mereka melakukan kesalahan dan penyimpan-gan dalam menjalani kehidupan yang ada.Perkawinan merupakan hal yang baik berangkat dari hal tersebut harus diberikan kebaikan didalamnya, apalagi mengikuti budaya baru dalam agama baru karena perkawinan yang ada.Persentasi muallaf Tinghoa di Kecamatan Pontianak Barat sangat besar karena dengan perkawinan dengan beda etnis.

Dalam kehadiran agama baru serta lingkungan baru yang beragama Islam, maka dalam pembinanan akhlak serta moral menjadi hal utama yang dilakukan serta diamalkan.Hal tersebut dapat dilihat dari kegunaan yang dapat dipetik dari hasil pembinaan akhlak para muallaf oleh guru agama dan para ulama Islam dalam membina serta membimbing para muallaf, yakni: terhindarnya anak-anak remaja dari tabiat-tabiat tercela dan sebagai langkah penanggulangan terhadap timbulnya penyimpangan ajaran serta tidak mengamalkan ajaran secara maksimal. Dengan demikian Pembina-an akhlak me- nurut Ibnu Maskawaih dapat memberi sumbangan positif bagi ketentraman dan keamanan masya-rakat dari kejahatan pada umum-nya; terutama gangguan dari kenakalan remaja. Sebab pada hakikatnya penjahat yang sudah dewasa merupakan perkembangan lebih lanjut dari kebiasaan melakukan kejahatan di waktu kecil; pada masa-masa perkem-bangan mental, yakni: masa remaja.

Dalam kehidupan dan hubungannya para muallaf harus selalu sejalan dengan ajaran Islam sehingga dapat membuat dirinya tidak mudah goyah keimanan serta selalu berpedoman pada ajaran yang benar yaitu: Al-qur'an dan Hadis. Dilihat dari perkembangan dan kemajuan industri sangat jelas banyak membawa pengaruh bagi kualitas kehidupan masyarakat baik dari sisi positif maupun negatif.Industri telah berperan besar terhadap perubahan hidup dan nilainilai berkehidupan di masyarakat. Masyarakat yang semula hidup ter-gantung dengan alam, lambat laun mulai termanjakan dengan berbagai kemudahan yang diberikan oleh industri, mulai dari industri rumah tangga seperti perkembangan mesin-mesin, alat-alat elektronik, makanan instan, serta kemajuan komunikasi/ IPTEK. Sisi lain dari perkembangan industri bagi masyarakat yang sangat tampak adalah bergesernya 
nilai-nilai tradisi masyarakat yang semula bersifat alami ke arah kemoderenan. Industri telah membuat hidup masyarakat berubah kearah instan, serba cepat, sehingga secara tidak langsung mempengaruhi pola hidup dan cara berpikir dalam keseharian.

Sisi positif dari hasil perkembangan industri dari segi sosial, perekonomian, dan politik adalah se-bagai berikut: Segi Sosial: Dalam sisi sosial hubungan masyarakat, Industri membuat pola hubungan menjadi semakin mudah dan cepat. Hal ini dikarenakan, Teknologi yang sekarang telah menjadi komoditi industri, begitu pula dengan persebaran informasi yang tidak lagi terbatas oleh tempat dan waktu.Segi Ekonomi: Dalam bidang ekonomi, industri membawa kemajuan berarti untuk perkembangan suatu negara, khususnya dalam segi pendapatan/devisa Negara, penyediaan lapangan pekerjaan, serta memini-malisir kemiskinan. Negara yang menguasai industri, biasanya mampu berbuat lebih banyak untuk mengelola perekonomian dunia; khususnya dalam nilai tukar mata uang.Segi Politik: Kemajuan industri sangat berkaitan erat dengan perkembangan politik.Politik mampu merubah dan mempengaruhi maju dan tidaknya industri. Hubungan dan kerjasama yang baik antar Negara bilateral/multilateral, didukung dengan stretegi yang matang akan membuat industri suatu Negara jauh lebih maju dan diperhitungkan. Contohnya industri mainan anak-anak dari Cina, yang kini menguasai pasar Asia.

Sisi negatif dan pengaruh hasil industri dari segi sosial, budaya dan moral. Segi Sosial dapat dilihat hasil industri secara tidak langsung membawa pola hubungan antar masyarakat menjadi semakin berjarak dan dipisahkan oleh kemoderenan seseorang. Misalnya: hubungan tetangga yang dipisahkan oleh status sosial (kaya-miskin). Segi budaya dan moral: industri berperan aktif merubah pola pikir, gaya hidup, kemandirian seseorang karena kemudahan yang diberikannya. Misalnya perkembangan/ hasil dari industri telekomunikasi seperti handphone, televisi, internet, walaupun membuat hubungan jarak jauh semakin dekat, tetapi memberi peluang besar dalam penyimpangan-penyimpangan sosial; kasus terhangat peredaran video porno artis yang semakin mudah diakses tidak saja oleh masyarakat dewasa tetapi juga anakanak. Yang pada akhirnya menambah jumlah aksi kriminal khususnya yang dilakukan oleh anak-anak di bawah umur.

Adanya musuh bersama dari luar menjadikan hal yang harus diperangi bersama.Karena para muallaf ini harus diberikan pembinaan dalam menjalani 
kehidupan yang ada.Pembentukan mentalitas sangat diperlukan.Sehingga pada hasil akhir penanaman mental terhadap muallaf Tionghoa dapat terlihat secara jelas dalam setiap aspek kehidupan ada lima hal seperti:

a. Mental yang tidak meremehkan mutu hasil karya sendiri

b. Mental yang tidak suka menerabas

c. Mental percaya diri sendiri

d. Mental disiplin tinggi

e. Mental selalu bertanggu jawab atas amanah yang diberikan

Proses yang diharapakan dalam asimilasi muallaf Tionghoa setelah masuk Islam seperti pada hasil wawancara dan observasi penelitian yang dilakukan dapat diketahui secara jelas bahwa:

a. Hubungan belum berjalan baik dengan tetangga baru yang beragama Islam, walaupun ada yang sudah berjalan dengan baik tetapi jumlahnya tidak terlalu banyak dibanding yang baiknya.

b. Belum sepenuhnya berani untuk melakukan pengamalan ajaran baru agama Islam yang hadir dalam kehidupannya.

c. Melukakan pembaruan kehidupan baik itu pandangan hidup maupun cara bergaul dengan lingkungannya.

d. Memperhatikan aspek-aspek keberislaman serta menentukan kehidupan yang baik dengan harapan selalu menjalankan ibadah.

e. Mendapatkan ketenangan hati dalam menjalankan kehidupan sehari-hari sehingga bentuk ini membawa suasanya menjadi lebih baik.

f. Mendapatkan kesucian jiwa dalam melihat realita kehidupan sehingga berdampak pada kedewasaan dalam bertindak (bertingkah laku).

g. Menghilangan rasa gelisah (was-was) yang ada dalam hati sehingga berdampak pada ketenangan hidupnya.

h. Mendapatkan kedamaian dan kerukunan dalam melakukan komunikasi dengan warga sehingga lingkungan menjadi aman dan tentram.

i. Mendapatkan keberkahan hidup sehingga kenikmatan hidup didapatkan secara mutlak dan hakiki.

j. Berakhlak mulia dalam setiap melakukan hubungan dengan para warga yang ada sehingga dampak pada hubungan sosial kemasyarakat menjadi lebih baik

k. Bertingkah laku sesuai dengan ajaran Islam dan berkata sopan santun setiap membangun komunikasi serta interaksi sosial kemasyarakatan yang ada sehingga kerukunan dan keharmonisan tercipta dalam masyarakat.

1. Berpikir Positif dengan musibah dalam hidup, sehingga dapat melihat bahwa 
musibah itu karena sebagai teguran dari Allah SWT atau ujian hidup diberian sehingga menjadikan motivasi berpikir positif yang begitu tinggi.

m. Bersabar dalam menjalankan kehidupan karena dalam hidup tidak ada satu orang pun manusia terlepas dari masalah dan gelombang (gejola) hidup.

Perbedaan ciri-ciri badaniah merupakan hal yang dialami secara serius oleh para muallaf Tionghoa karena dengan memiliki ciri-ciri badan yang menjolok dari kelompok etnis lain maka kelompok etnis ini mudah dikenali secarajelas, contohnya warna kulit biasa dan mayoritas memiliki warna putih. Dalam hal ini diperlukan sekali sikap multikultural walaupun dalam satu agama.Berangkat dari agama Islam ini memiliki aneka suku seperti: Melayu, Madura, Cina, Jawa, Padang, dan lainnya maka harus dikembangkan secara serius makna multikultural dengan sesama. Multikultural adalah sebuah ideologi yang menekankan pengakuan dan penghargaan pada kesederajatan perbedaan kebudayaan. Tercakup dalam pengertian kebudayaan adalah para pendukung kebudayaan, baik secara individual maupun secara kelompok, dan terutama ditujukan terhadap golongan sosial askriptif yaitu sukubangsa, ras, gender, dan umur. Masyarakat akan melihat fenomena kehidupan yang tensinya cukup tinggi dan pemicu konflik etnis yang sangat tinggi berangkat dari hal tersebut mereka selalu melihat bahwa para muallaf Tionghoa harus cepat mengubah pola serta cara pandang kearah budaya adan agama Islam secara benar. Kalu tidak dilakukan maka hal tersebut akan menjadi hambatan secara serius diterima atau tidaknya kelompok etnis muallaf Tionghoa dalam masyarakat Islam secara global.

In-group feeling yang sangat kuat pada golongan Tionghoa, sehingga mereka lebih kuat mempertahankan identitas sosial dan kebudayaannya yang eksklusif. Kekuatan ini menjadi mereka terlihat selalu tertutup dan tidak mau membuka diri secara penuh kepada kelompok etnis lainnya. Dan timbul rasa dan pikiran bahwa kelompok etnisnya yang paling baik dan sempurna, sehingga mempersempit ruang lingkup untuk bergerak dan penciptaan hubungan sosial kemasyarakat dengan baik dengan orang Islam yang juga merupakan keluarga mereka dari hasil perkawinan yang ada juga kepada orang Islam lainnya yang menjadi warga dan tetangga sekitar tempat tinggal mereka.

Hubungan sosial kemasyakatan sesama tertutup. Hal tersebut diperlihatkan para muallaf Tionghoa seperti merasa orang baru sehingga mau bergaul serta melakukan komunikasi antar sesama akan terganggu, takut, ada rasa malu dan 
belum siap bergaul. Hal tersebut disebabkan oleh kemampuan yang kurang atau merasakan orang asing dalam dunia barunya. Dalam hal ini perlu hadirnya manusia yang siap menjembatani para muallaf baru untuk selalu berhubungan dengan menge-depankan rasa sosial dan selalu membangun solidaritas sesama muslim.

Beberapa hal sebagai faktor penghambat dan penghalang proses asimilasi selain memperkuat dan menjaga indentitas dengan baik seperti diantaranya: terisolasi golongan tertentu di dalam masyarakat (biasanya golongan minoritas). terisolasinya suatu golongan sering menjadi hambatan komunikasi antar kelompok, sehingga menyulitkan bagi kelompok tersebut untuk terjadi asimilasi. Kurangnya pengetahuan tentang kebudayaan yang dihadapi, sehingga dengan pengetahuan kurang akan menimbulkann salah mengerti terhadap kebudayaan kelompok lain. Perasaan takut terhadap kekuatan suatu kebudayaan yang dihadapi. Perasaan ini lebih banyak disebabkan oleh takut atau khawatir terhadap tergesernya kebudayaan yang sudah menjadi pengangan hidup bagi kelompok tersebut.Perasaan kebudayaan golongan tertentu merasa lebih tinggi daripada kebudayaan kelompok lain. Perasaan ini disebut sebagai superioritas kultural, dimana kecenderungan kelompok untuk menganggap kebuda-yaannya memiliki peradaban yang lebih tinggi disbanding dengan kebudayaan kelompok lain. Perbedaan rasial. Yang dimaksud dengan perbedaan ras adalah perasaan di mana ras tertentu merasa lebih tinggi dibanding dengan ras lain.Perasaan kekelompokkan yang kuat (in group feeling). Perasaan ini acap kali disebut etnosentrisme, yaitu sikap yang menjadi-kan kebudayaan di dalam kelompoknya sebagai tolak ukur untuk mengukur baik dan buruknya kebudayaan lain.

Golongan minoritas mengalami gangguan dari golongan penguasa. Golongan minoritas yang terdapat tekanantekanan politik dari penguasa pernah terjadi ketika rezim Sadam Husein berkuasa. Perbedaan kepenting-an. Perbedaan kepentingan biasanya melahirkan sikap dan tindakan yang berbeda-beda yang perbedaan itu sukar sekali dicapai pembauran. Perbedaam kepentingan yang paling mencolok yaitu perbedaanperbedaan yang terdapat dalam tubuh partai politik yang sama-sama menghendaki ke-kuasaan pada kelompok partai politik yang dibawahnya.

Dominasi ekonomi yang menyebabkan timbulnya sikap tinggi hati. Dominasi ekonomi tersebut bersumber pada fasilitas-fasilitas ada dalam kehidupan 
secara nyata dalam menjalani kehidupan.Berangkat dari hal tersebut banyak dari muallaf Tionghoa setelah masuk Islam mengalami kemerosotan dari sektor ekonomi.Hal ini disebabkan dengan mereka melakukan pindah agama mereka dikeluarkan dari orang yang mendapatkan warisan dari keluarga dan orang tua.Dan paling parah sampai tidak lagi diperhatikan bagaimana kehidupan ekonominya setelah mereka masuk Islam.Pada dasarnya mereka juga belum memahami secara utuh dan menyeluruh dari makna ekonomi dalam Islam. Karena dalam Islam hidup bukan satu-satu hanya mengejar nilai ekonomi dan hal terpenting seberapa mampu menjalankan syariat Islam secara baik dan benar dengan sendirinya nilai ekonomi akan datang dan menjadikan dirinya orang besar hati dan besar dalam makna ekonomi.

Dengan tidak mendapatkan warisan secara langsung dari keluarga asal dapat menyebabkan motivasi serta semangat hidup lemah. Dengan lemahnya motivasi serta semangat hidup maka akan membawa masyarakat tersebut selalu berada pada garis kemiskinan atau segala hal yang kurang baik dilakukan karena pandangan serta orientasi hidup hanya mau senangnya saja. Dalam hal mencari uang hanya terpikir cepat dan besarnya saja selalu dikedepankan tidak memikirkan apa efek serta resiko yang akan diterima dalam melakukan hal tersebut. Terkadang orang yang memiliki motivasi kurang dan semangat hidup lemah akan terlihat hidupnya tidak ada arahan yang jelas serta selalu mersakan hidupnya nyaman dan tidak tertantang dengan orientasi kedepan (masa depan) lebih baik lagi.

Dengan lemahnya motivasi kerja Akan berdampak paad bertambah pengangguran.Dalam dunia sekarang pengangguran memang salah satu faktor atau hal yang harus dihilangkan minimal ditekan keangka paling kecil, karena hal tersebut akan membuka peluang yang besar dalam melakukan kejahatan dan melanggar aturan.Karena kurang mau bekerja keras. Bekerja keras adalah salah satu hal yang dapat menghantarkan seseorang itu kedalam hidup yang lebih baik.Karena didalamnya dijanjikan banyak hal yang keuntungannya luar biasa. Orang yang bekerja keras biasanya selalu memiliki sifat menghargai diri sendiri dan orang lain menjadi lebih tinggi karena setiap hasil pekerjaan orang itu adalah tetesan keringat serta perjuangan hidup menuju lebih baik. Terlepas dari apakah hasil tersebut sesuai atau tidak dengan kemauan orang banyak karena dia sudah berusaha dan itu merupakan batasan kemampuan yang dimiliki. 


\section{Kesimpulan}

Kondisi Sosial Kelompok Muallaf Tionghoa Di Kecamatan Pontianak Barat

a. Berangkat dari hal tersebut masuknya Islam mereka banyak faktor:

b. Masuk Islam karena menikah

c. Masuk Islam karena mendapatkan hidayat atau petunjuk dari Allah SWT.

d. Masuk Islam karena sudah mengenal dunia Islam sebelumnya.

e. Masuk Islam melihat manfaat serta perubahan dari kehidupan seperti rasa puas, kedamaian, kesejahteraan, kesabaran dan tingkat menyukuri nikmat sangat tinggi.

f. Masuk Islam membawa barokah karena dengan masuk Islam mereka merasakam hidup terarah dan hasil dari kerja mereka juga dapat dirasakan baik untuk nafkah kehidupan sehari-hari maupun untuk ibadah yang akhirnya mengharapkan ridho dari Allah SWT semata.

g. Masuk Islam karena ingin mendapatkan ketenangan jiwa dan kesucian hati dalam menenjalani kehidupan.

Proses Asimilasi Muallaf Tionghoa Setelah Masuk Islam Di Kecamatan Pontianak Barat, Proses asimilasi Mullaf Tionghoa setelah mereka masuk Islam yang dapat diketahui secara jelas bahwa:

a. Hubungan belum berjalan baik dengan tetangga baru yang beragama Islam. b. Belum sepenuhnya berani untuk melakukan pengamalan ajaran baru agama Islam yang baru hadir dalam kehidupannya.

c. Mealukakan pembaruan kehidupan baik itu pandangan hidup maupun cara bergaul dengan lingkungannya.

d. Memperhatikan aspek-aspek keberislaman serta menentukan kehidupan yang baik dengan harapan selalu menjalankan ibadah serta bertingkah laku sesuai dengan ajaran Islam.

Hambatan-Hambatan yang dialami oleh kelompok muallaf tionghoa di kecamatan Pontianak Barat. dalam kehidupan sering muallaf Tionghoa terjadinya sistem sosial tidak berjalan dengan baik, hal tersebut dikarenakan beberapa faktor seperti:

a. Hubungan sesama masih terlihat tertutup.

b. Pengangguran yang banyak.

c. Motivasi serta semangat hidup lemah.

d. Karena kurang mau bekerja keras.

e. Kurang menghargai kualitas dan kemampuan diri.

f. Selalu beorientasi pribadi diatas kepentingan umum.

Dalam komunikasi serta interaksi yang dilakukan oleh kelompok Muallaf Tionghoa di Kecamatan Pontianak Barat Kota Pontianak mengalami berbagai hambatan diantaranya seperti: 
a. Proses komunikasi yang terbagun tidak berjalan baik.

b. Pengakuan terhadap keberadaannya dalam dunia baru belum sepenuhnya.

c. Kurangnya waktu dalam belajar agama Islam

d. Minimnya guru untuk memberikan pembinaan serta penanaman mental, moral juga etika.

e. Masih terbawa (tebanyang) dengan tradisi agama lama.

f. Beribadah masih mengharapkan hal nyata dalam kehidupan.

g. Selalu mengedapan ekonomi dalam setiap hal dilakukan.

h. Keterlibatan oraganisasi pembinaan baik itu formal maupun nonformal masih sangat kurang.

\section{E. Daftar Pustaka}

Alqadrie, Syarif Ibrahim. 2011. "Matari Akan Terbit Di Barat: Indentitas Budaya, Identitas Etnis dan Keagamaan, Kesadaran Etnis". Pontianak: PT. Borneo Tribune Press.

Asmara, Uray Husna. 2004. "Penulisan Karya Ilmiah”. Pontianak: Fahruna Bahagia.
Liliweri, Alo. 1997. "Komunikasi Antarpribadi”. Bandung: PT. Citra Aditya Bakti.

Moleong, Lexy J. 2004. "Metodologi Penelitian Kualitatif”. Bandung: PT Remaja Rosda Karya.

Nawawi, Hadari. 1985. "Motode Penelitian Bidang Sosial”. Yogyakarta: Gadjah Mada University Press.

Parwadi, Redatin dkk. 2009. “Buku Pedoman Penulisan Usulan Dan Tesis". Program Magister Ilmu Sosial Universitas Tanjungpura Pontianak.

Rasyid, Harun. 2000. "Penelitian Kualitatif Bidang Ilmu Sosial dan Agama”. Pontianak: Kopma STAIN.

Setiadi, Elly M. dan Kolip, Usman. 2011. "Pengantar Sosiologi Pemahaman Fakta dan Gejala Permasalahan sosial: Teori, aplikasi, dan Pemecahannya”. Jakarta: Prenada Media Group.

Soekanto, Soejono. 2002. "Sosiologi Suatu Pengantar".Jakarta: PT. Raja Grafindo Persada.

Soekanto, Soerjono. 1993. "Kamus sosiologi Edisi Baru”. Jakarta: PT. Raja Grafindo Persada. 